\title{
The tectonic emplacement of Sumba in the Sunda-Banda Arc: paleomagnetic and geochemical evidence from the early Miocene Jawila volcanics
}

\author{
Hans Wensink * , Manfred J. van Bergen \\ Faculty of Earth Sciences, Utrecht University, Budapestlaan 17,3584 CD Utrecht, The Netherlands
}

Received 12 October 1994; accepted 24 April 1995

\begin{abstract}
The island of Sumba is a continental fragment in the fore-arc region near the transition between the Sunda Arc and Banda Arc in southeastern Indonesia. Paleomagnetic and geochemical evidence from the early Miocene volcanics of the Jawila Formation in western Sumba constrain the final drift stage and tectonic emplacement of the island. The lavas range from predominantly andesites to dacites, and display textural evidence for a weak metamorphism. Rock magnetic and mineral chemical data point to pseudo-single- to multi-domain (titano)magnetite $\left(\mathrm{Fe}_{2.5-3} \mathrm{Ti}_{0.5-0} \mathrm{O}_{3}\right.$ ), with grain sizes up to $10 \mu \mathrm{m}$, as the main carrier of remanence. The Jawila Formation reveals a ChRM direction with declination $=4.6^{\circ}$, inclination $=$ $-19.2^{\circ}, \alpha_{95}=9.9^{\circ}$ and a paleolatitude of $9.9^{\circ} \mathrm{S}$, which corroborates earlier results (Chamalaun and Sunata, 1982). Taking paleomagnetic evidence from other formations on the island into account, we conclude that the Sumba fragment has occupied approximately its present position since the Miocene. The calc-alkaline affinity and trace-element signatures of the lavas point to an origin in an arc environment. This occurrence of subduction-related volcanic activity in the early Miocene on Sumba implies that a volcanic arc existed south of the present-day East Sunda Arc, or that the island was located within the latter arc between Sumbawa and eastern Flores, and still had a minor southward drift to cover.
\end{abstract}

\section{Introduction}

In eastern Indonesia major rearrangements at the converging Southeast Asian, Indo-Australian and $\mathrm{Pa}-$ cific plates have generated a number of continental fragments whose origin and tectonic history is often obscure (Hamilton, 1979). The island of Sumba is currently located in a tectonically puzzling position within the fore-arc realm of the Sunda-Banda subduction system (Fig. 1). The island is bounded on its west and its east side by deep fore-arc basins, the

\footnotetext{
* Corresponding author.
}

Lombok basin and the Savu Basin, respectively. In the inner arc to the north of these basins present-day volcanic activity marks the islands of Sumbawa and Flores, which are constructed on oceanic crust. Subduction of the northward-moving oceanic part of the Indian-Australian plate occurs along the Sunda Trench; subduction of the continental part takes place further east along the Timor Trough. Sumba is located to the north of the trench near the transition between these oceanic and continental domains. In the west, Indian oceanic crust is being subducted, while to the east the margin of the Australian continent has entered the trench and is colliding with the island arc. 


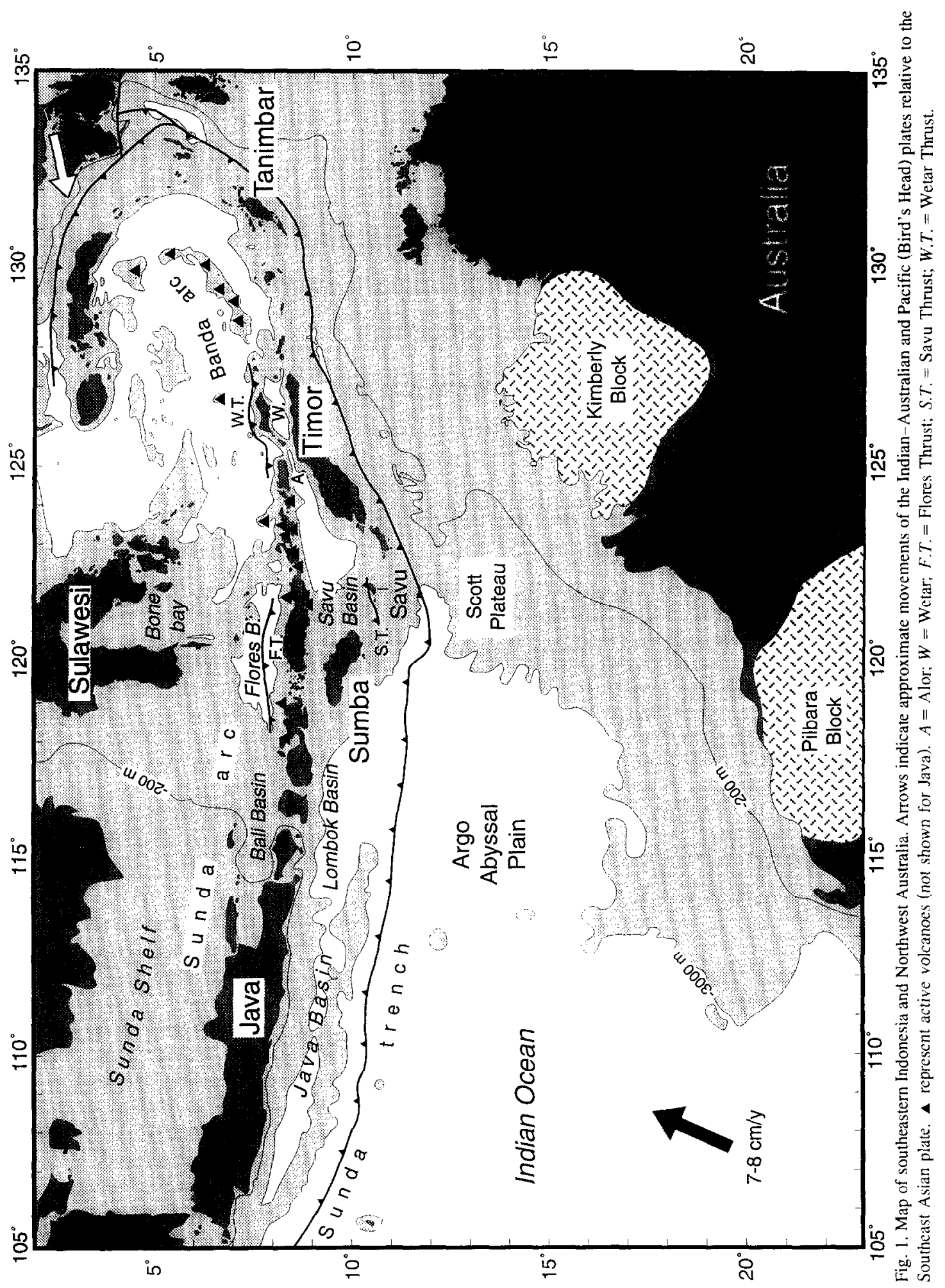


Sumba is generally regarded as an isolated microcontinent drifted away from an unknown original position. There are three different views on its provenance: (a) Sumba once formed part of the Australian continent from which it became detached, drifted away and performed a clockwise rotation (AudleyCharles, 1975; Norvick, 1979; Otofuji et al., 1981); (b) Sumba's original location was to the north at the margin of Southeast Asian Sundaland from which the fragment split off, drifted to the south and performed a large counterclockwise rotation (Von der Borch et al., 1983; Audley-Charles, 1985; AudleyCharles et al., 1988; Rangin et al., 1990a, Rangin et al., 1990b; Simandjuntak, 1993; Wensink, 1994); (c) the fragment had an isolated position within the Tethys region in Mesozoic times (e.g., see Hamilton, 1979).

In this paper we document paleomagnetic and geochemical results on early Miocene volcanics, which constrain the final stages of Sumba's drift since late Mesozoic times. Preliminary paleomagnetic data were presented earlier by Chamalaun and Sunata (1982) and Wensink (1994). The results, in conjunction with the evidence from older rock series (Wensink, 1994), are consistent with a northern provenance, and are used to elucidate the island's emplacement in its present-day setting.

\section{Tectonic setting of the Sumba continental frag- ment}

The geology of Sumba is well documented (Van Bemmelen, 1949; Laufer and Kraeff, 1957; Hamilton, 1979; Chamalaun et al., 1981; Effendi and Apandi, 1981; Burrolet and Sallé, 1982; Von der Borch et al., 1983; Fortuin et al., 1992). Recent summaries can be found in Fortuin et al. (1994) and Wensink (1994). Structural and stratigraphic information on the adjacent Lombok and Savu basins has been given by Silver et al. (1983), Karig et al. (1987), Van Weering et al. (1989) and Van der Werff et al. (1994b, 1995a, b).

The stratigraphic sequence on Sumba, built up by mostly marine sediments and intercalations of igncous rocks, is late Cretaccous and younger in age. Apart from the late Cretaceous marine sediments of the Lasipu Formation, deformation is faint or absent.
Small unconformities occur in the late Paleogeneearly Neogene shallow marine sediments beneath deep marinc scdiments of the Sumba Formation on eastern Sumba or its equivalent with shallow marine sediments of the Waikabubak Formation on western Sumba.

The structure of the island and the adjacent offshore areas is characterized by uplifted crustal blocks along old WNW-ESE to W-E linear trends; the blocks are slightly tilted to the north and northeast (Van Weering et al., 1989; Fortuin et al., 1994). Apart from these vertical movements the basement acted as a rigid block since the early Paleogene. The absence of major deformation corresponds with Sumba's position just outside the main collision zone; this strongly contrasts with the heavily tectonized formations on Timor and on other outer arc islands further tot the east (see Harris, 1991). At least $3 \mathrm{Myr}$ ago (e.g., Abbott and Chamalaun, 1981), but perhaps already $8 \mathrm{Myr}$ ago (Berry and Mc Dougall, 1986) the passive continental margin of Australia started to collide with the island arc.

Much of the structural development of the emerged and submarine outer arc highs on the overriding plate along the trench can be explained by accretionary wedge forming mechanisms (Hamilton, 1979). A major transition in the accretionary wedge can be observed to the south of Sumba. At $118^{\circ} 30^{\prime} \mathrm{E}$ a N-trending left lateral strike-slip fault offsets the wedge (Van der Werff, 1995). East of it, where the continental-type Scott Plateau, a submarine part of the northwestern Australian margin, is currently involved in collision and subduction, the thickness of the pile of accreted sediments increases from 600 to $1800 \mathrm{~m}$ and the width of the prism from 70 to 110 $\mathrm{km}$. At $121^{\circ} \mathrm{E}$ the accretionary wedge is $140 \mathrm{~km}$ wide and shows a bulge to the south; the trench axis has shifted southward as well. The formation of the large wedge of continental margin sediments coincides with the widening of the arc-trench gap (cf., Johnston and Bowin, 1981).

Timor and other islands eastward in the outer arc are marked by a strong recent uplift (Chappell and Veeh, 1978; Barber, 1981; De Smet et al., 1989). According to Hamilton (1979) continental crust of the passive Australian margin, subducted along the Timor Trough, has reached at least the inner margin of the outer arc. Geochemical and isotopic signatures 
of the recent volcanics in the inner arc on both sides of the extinct Alor-Wetar sector north of Timor suggest that subduction of the leading edge of the margin even has reached magma sources deeper than $100 \mathrm{~km}$ (Hilton et al., 1992; Van Bergen et al., 1993). As the preceeding oceanic crust may become detached from the buoyant continental part of the slab (Eva et al., 1988), the rapid recent uplift of the fore-arc could be explained by rebound forces (Charlton, 1991). Gradual uplift of Sumba was initiated in the latest Miocene-early Pliocene (Fortuin et al., 1994); the late Pliocene-Quaternary uplift rate has been estimated to be about $0.5 \mathrm{~mm} / \mathrm{yr}$ (Pirazzoli et al., 1991; Fortuin et al., 1992).

\section{The Jawila volcanics: field relations, sample locations and petrographic characteristics}

The early Miocene volcanics studied here belong to the Jawila Formation on western Sumba (Fig. 2). Lavas of mainly andesitic composition are exposed

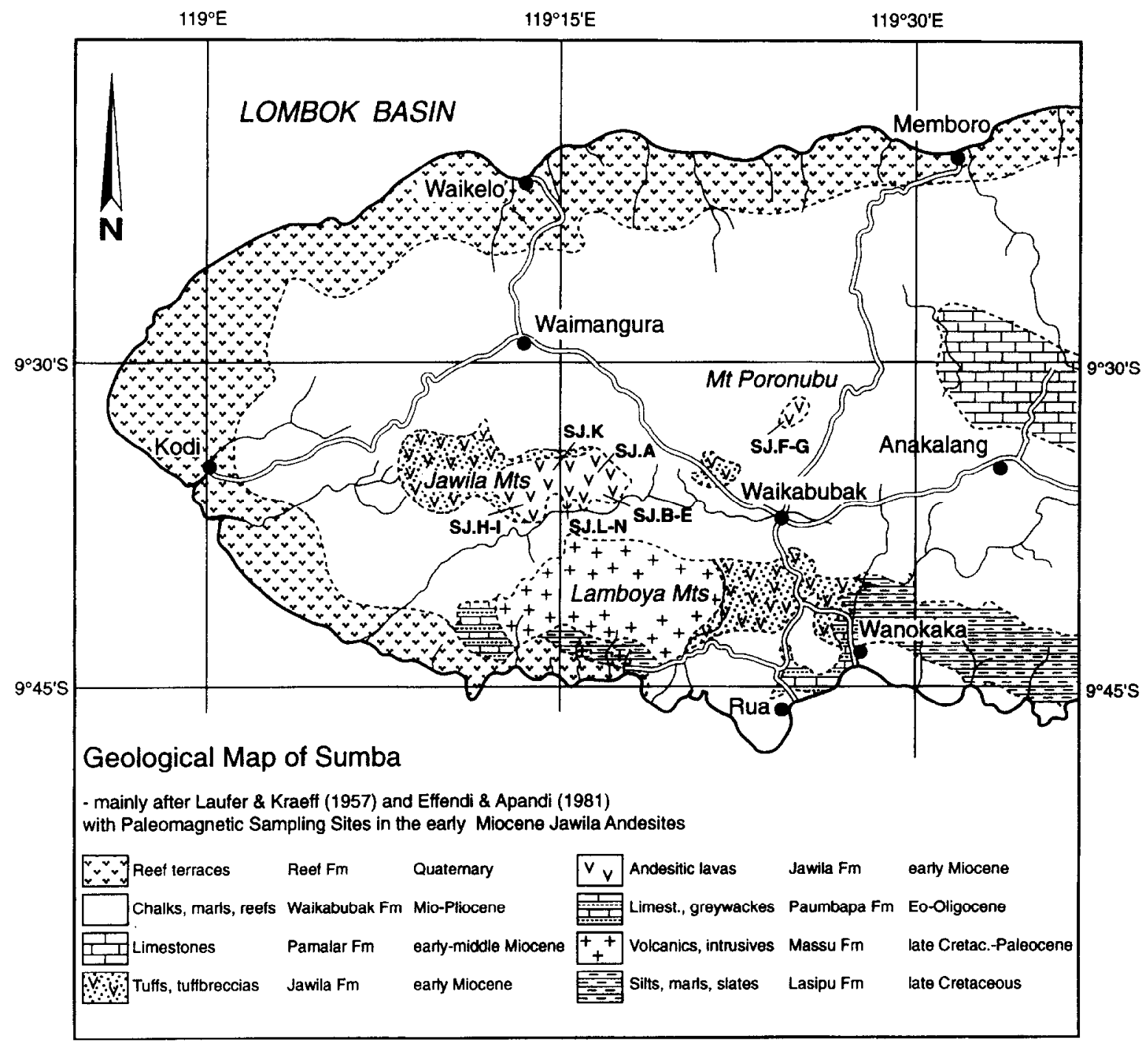

Fig. 2. Geological map of western Sumba with the sampling localities for paleomagnetic and geochemical research. 
in a rather limited area chiefly in the Jawila Mountains approximately $15 \mathrm{~km}$ west of Waikabubak, the main town on western Sumba. A small outcrop of lavas occurs in the Poronubu Hills, $10 \mathrm{~km}$ north of Waikabubak. Tuffs, tuff sands, tuff breccias and agglomerates, often containing silicified tree trunks and other plant remains, are found both to the west of the lava exposures in the Jawila Mountains and south of Waikabubak. Some lignite is present in the western area.

The volcanic suite overlies either late Cretaceous Lasipu sediments, early Tertiary volcanics of the South Coast Mountains, or late Eocene and Oligocene limestones and greywackes. In general, the volcanics of the Jawila Formation slightly dip to the north and are overlain by the shallow marine deposits of the western facies of the Neogene Waikabubak Formation.

A total number of 75 oriented hand samples have been collected at eleven sites in the Jawila Mountains and at two sites in the Poronubu Hills (Fig. 2). The Jawila Mountains consist of rough and rather steep W-E-trending hills with badly accessible woods. Outcrops were found in a number of small rivers. The quality of the exposures does not always permit a reliable tilt correction. Columnar jointing, which is often developed in the lavas, was sometimes a helpful criterion.

Most of the rocks studied are porphyritic andesites, while two samples (flows SJ.A and SJ.H) are dacitic in composition. All are affected by some degree of alteration. Primary phenocryst assemblages includc clinopyroxene, plagioclase and $\mathrm{Fe}-\mathrm{Ti}$ oxide. Apatite, sulphides and sometimes ilmenite are among the accessorial minerals. Secondary assemblages of chlorite, carbonate, epidote, sphene, albite, quartz, $\mathrm{K}$-feldspar, actinolite are indicative of (very) low degree metamorphism, which is widespread in most pre- and early Tertiary rocks of Sumba (Chamalaun et al., 1981).

\section{Paleomagnetic data}

\subsection{Paleomagnetic analysis of the characteristic remanence}

The specimens with a diameter of $25 \mathrm{~mm}$ and a length of $22 \mathrm{~mm}$ which were drilled from the hand- samples have been subjected to standard paleomagnetic procedures, and have been measured on a spinner magnetometer. The specimens have been treated with partial, progressive demagnetization techniques, the majority of them with alternating magnetic field (AF method). Progressive heating was only partially successful, because in the furnace the specimens exploded after heating at temperatures between 300 and $400^{\circ} \mathrm{C}$; hence, maximum blocking temperatures could not be determined in this way. AF treatment in fifteen successive steps up to $75 \mathrm{mT}$ peak value has been applied to at least two specimens per site; the remaining specimens of the site received an $\mathrm{AF}$ treatment in eight to twelve successive steps.

The demagnetization diagrams illustrate the behaviour of the remanence vector during the progressive demagnetization (Fig. 3). Many specimens show a rapid decrease in remanence intensity after $\mathrm{AF}$ treatment in low fields only as a result of the removal of a viscous component; the viscous component, most likely caused by the slightly weathered condition of the lavas, usually disappears after treatment between 5 and $10 \mathrm{mT}$ peak fields (Fig. 3, e.g., SJ.D2 and SJ.I3A). Very often, also a secondary component of remanence can be discerned (Fig. 3, e.g., SJ.D2 and SJ.E7A). In Fig. 3 it can be seen that after AF treatment between 20 and $25 \mathrm{mT}$ a component of remanence remains, that generally is characteristic. In cases, when at subsequent demagnetization a spurious component becomes introduced, no characteristic remanence direction of high quality can be obtained (SJ.N3). Spccimen SJ.I3A (Fig. 3) forms an example of $\mathrm{AF}$ treatment up to $25 \mathrm{mT}$ peak value with subsequent heating up to $430^{\circ} \mathrm{C}$, after which the specimen exploded in the furnace.

A compilation of the characteristic remanence directions with their statistics derived from the Jawila volcanics is presented in Table 1. The data derived from site SJ.F are rather poor. The samples from this site as well as those from site SJ.G have been collected in a small rivulet in the badly exposed Poronubu Hills, $10 \mathrm{~km}$ north of Waikabubak. Although reliable paleomagnetic data could be obtained from site SJ.B, the site mean direction cannot be used in the ultimatc compilation, becausc of a possible tilt of the basalt flow of unknown size. The data from sites SJ.B and SJ.F have been excluded from 


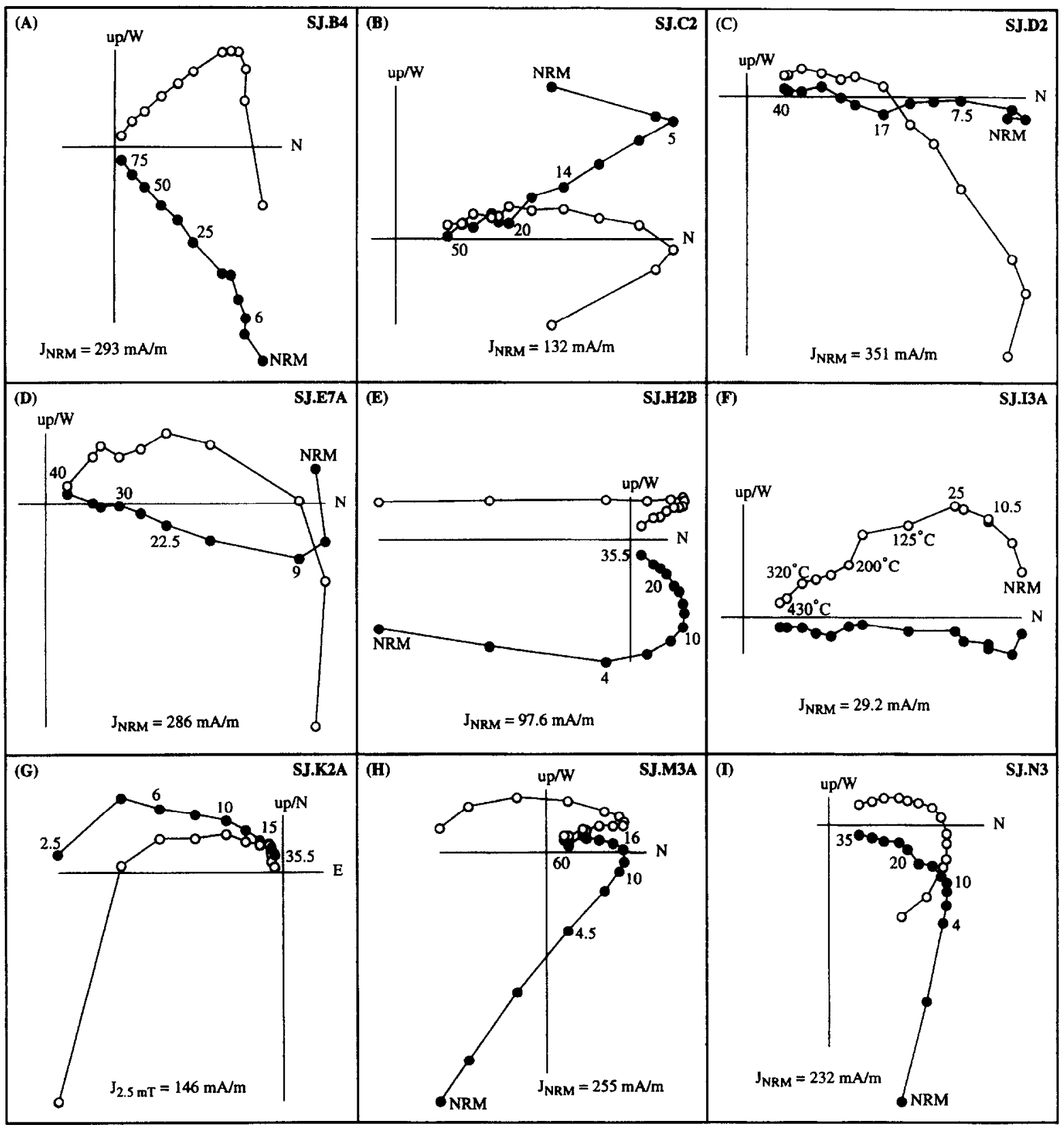

Fig. 3. Diagrams showing the progressive demagnetization of specimens of the Jawila Formation of early Miocene age. The plotted points represent successive positions of the resultant remanence vector in orthogonal projection. $O$ and $O$ denote the projections on a horizontal and on a vertical plane, respectively. Field peak strenghts are given in $\mathrm{mT}$, and temperatures are given in ${ }^{\circ} \mathrm{C}$. All specimens have been treated with alternating magnetic fields (AF method), except specimen SJ.I3 that has been treated with AF up to $25 \mathrm{mT}$ peak value, and successively with heating. $J_{\mathrm{NRM}}$ is the initial remanence intensity in $\mathrm{mA} / \mathrm{m}$ (milliampères per meter), and $J_{2.5 \mathrm{mT}}$ the intensity after AF treatment of $2.5 \mathrm{mT}$. 
the final analysis. The data in Table 1 illustrate that exclusion of data of more sites would change the final result only slightly.

In our view, the characteristic remanence of these andesites represents the primary magnetization, because (a) the results obtained with both $\mathrm{AF}$ and heating are consistent, (b) there is no strong magnetic overprinting and (c) one site shows a reversed ChRM direction.

\subsection{Hysteresis measurements}

Rock magnetic properties of the Jawila lavas, based on hysteresis curves, have been determined for at least one specimen per site. These data are indispensable to get insight in both the carriers of the magnetic remanence and the grain size of the minerals. The curves have been determined with a MicroMag 2900, manufactured by Princeton Measurements Corporation. From each specimen at least three flakes have been measured. A magnetic field with increasing strength with a maximum value of $500 \mathrm{mT}$ has been applied.

From these measurements the remanent saturation magnetization $\left(J_{\mathrm{rs}}\right)$, the saturation magnetization $\left(J_{\mathrm{s}}\right)$, the remanent coercive force $\left(H_{\mathrm{cr}}\right)$ and the coercive force $\left(H_{\mathrm{c}}\right)$ have been determined. The remanent coercive force is the strength of the field needed to reduce $J_{\mathrm{rs}}$ to zero remanence; the coercive force is the strength of the field needed to reduce $J_{\mathrm{s}}$ to zero. The mean $J_{\mathrm{rs}}$ with a value of $520 \pm 200$ $\mathrm{A} / \mathrm{m}$ is approximately 1700 times the value of the mean initial remanence intensity with $0.305 \pm 0.165$ A $/ \mathrm{m}$; the mean $J_{s}$ is fourteen times greater than $J_{\text {rs }}$ (Table 2).

$H_{\mathrm{cr}}$ values have been determined as well on a PM 4 pulse magnetiser (manufactured by H.N. Böhnel) and have been measured on a digitized spinner magnetometer based on a Jelinek JR-3 drive unit. These $H_{\text {cr }}$ values with a mean value of $26.6 \pm 7.6 \mathrm{mT}$ is only slightly different from those determined with the MicroMag (Table 2, $26.3 \pm 4.8$ ). The $H_{\text {cr }}$ values indicate (titano)magnetite with a small grain size of approximately $10 \mu \mathrm{m}$ and less (Hartstra, 1982).

A number of specimens have been analysed by applying a direct field of up to $1.5 \mathrm{~T}$ in order to assess whether or not they acquired the maximum isothermal remanent magnetization $\left(\mathrm{IRM}_{\max }\right)$; the
Table 1

Paleomagnetic data from volcanics of the Jawila Formation of early Miocene age, western Sumba

\begin{tabular}{|c|c|c|c|c|c|c|}
\hline Site & $N$ & $E$ & $D\left(^{\circ}\right)$ & $I\left(^{\circ}\right)$ & $k$ & $\alpha_{95}$ \\
\hline SJ.A & 9 & 5 & 353.3 & 0.6 & 9.2 & 18.0 \\
\hline SJ.B & 8 & 0 & 50.9 & -24.7 & 44.2 & 8.4 \\
\hline SL.C & 11 & 2 & 355.4 & -13.3 & 40.4 & 7.3 \\
\hline SJ.D & 11 & 1 & 358.9 & -25.3 & 28.0 & 8.8 \\
\hline SJ.E & 10 & 4 & 10.1 & -27.3 & 14.5 & 13.1 \\
\hline SJ.F & 15 & 0 & 221.4 & -51.3 & 1.7 & 45.7 \\
\hline SJ.G & 10 & 6 & 207.1 & 1.9 & 41.9 & 7.6 \\
\hline SJ.H & 10 & 0 & 17.4 & -35.5 & 50.0 & 6.9 \\
\hline SJ.I & 10 & 2 & 10.1 & -22.5 & 93.8 & 5.0 \\
\hline SJ.K & 7 & 4 & 353.7 & -28.4 & 13.1 & 17.3 \\
\hline SJ.L & 6 & 5 & 11.1 & 2.4 & 13.9 & 18.6 \\
\hline SJ.M & 13 & 0 & 359.6 & 28.3 & 45.8 & 6.2 \\
\hline SJ.N & 11 & 0 & 353.5 & -27.1 & 53.0 & 6.3 \\
\hline \multicolumn{7}{|c|}{ Overall mean after $(a)$ and before $(b)$ tilt correction } \\
\hline $\mathrm{SJ}^{\prime}(\mathrm{a})$ & 11 & 2 & 4.6 & -19.2 & 22.4 & 9.9 \\
\hline$S J^{\prime}(b)$ & 11 & 2 & 5.5 & -13.3 & 18.5 & 10.9 \\
\hline$S J^{\prime \prime}(a)$ & 10 & 3 & 3.8 & -21.3 & 2.4 .9 & 9.9 \\
\hline$S J^{\prime \prime}(b)$ & 10 & 3 & 4.9 & -14.9 & 18.2 & 11.6 \\
\hline$S \mathbf{J}^{\prime \prime \prime}(\mathrm{a})$ & 8 & 5 & 2.1 & -26.2 & 63.8 & 7.0 \\
\hline$S J^{\prime \prime \prime}(b)$ & 8 & 5 & 3.2 & -20.2 & 31.5 & 10.0 \\
\hline
\end{tabular}

$N$ and $E$ are the number of specimens included in, and excluded from the final analysis, respectively; $D$ and $I$ are the declination and inclination of the characteristic remanence direction after tilt correction; $k$ is the precision parameter; $\alpha_{95}$ is the semi-angle of the $95 \%$ cone of confidence (Fisher, 1953); $\mathrm{SJ}^{\prime}$ excludes sites $\mathrm{B}$ and F; $\mathrm{SJ}^{\prime \prime}$ excludes sites B, F and L; SJ"' excludes sites A, B, F, $G$ and $L$.

$\mathrm{IRM}_{\max }$ value turned out to be approximately the same as the $J_{\mathrm{rs}}$ value, indicating that the application of $500 \mathrm{mT}$ with the MicroMag 2900 is sufficient to reach complete saturation. Normalized remanent hysteresis curves of specimens from the Jawila volcanics are given (Fig. 4) with maximum values of the direct field applied up to $200 \mathrm{mT}$ (SJ.H2B) and $500 \mathrm{mT}$ (SJ.M4A). The rapid increase of remanence intensity with the increase of the applied direct field points to a prevalent presence of (a) mineral(s) of low coercivity, e.g., (titano)magnetite. Curie balance measurements confirmed the importance of (titano)magnetite as carrier of remanence.

The $J_{\mathrm{rs}} / J_{\mathrm{s}}$ ratio has been plotted against the $H_{\mathrm{cr}} / H_{\mathrm{c}}$ ratio for thirteen Jawila specimens in Fig. 5. The majority of our data fall in the PSD realm, and some in the MD realm (Day et al., 1977). 
Table 2

Some rock magnetic properties of specimens from the Jawila Formation, Sumba, Indonesia

\begin{tabular}{|c|c|c|c|c|c|c|c|c|}
\hline Specimen & $\begin{array}{l}J_{0} \\
(\mathrm{~A} / \mathrm{m})\end{array}$ & $\begin{array}{l}J_{\mathrm{s}} \\
(\mathrm{E}+3 \mathrm{~A} / \mathrm{m})\end{array}$ & $(\mathrm{E}+3 \mathrm{~A} / \mathrm{m})$ & $J_{n} / J$ & $\begin{array}{l}H_{c r} \\
(\mathrm{mT})\end{array}$ & $\begin{array}{l}H_{\mathrm{c}} \\
(\mathrm{mT})\end{array}$ & $H_{\mathrm{cr}} / H_{\mathrm{c}}$ & $\begin{array}{l}H_{\mathrm{cr}}^{\prime} \\
(\mathrm{mT})\end{array}$ \\
\hline SJ.A6 & 0.49 & 0.41 & 5.13 & 0.081 & 19.3 & 7.0 & 2.8 & 23.2 \\
\hline SJ.B4 & 0.29 & 0.28 & 6.30 & 0.044 & 25.9 & 5.4 & 4.8 & 24.8 \\
\hline SJ.C3 & 0.17 & 0.37 & 8.16 & 0.046 & 24.1 & 5.8 & 4.1 & 21.6 \\
\hline SJ.D5 & 0.42 & 0.61 & 8.55 & 0.071 & 26.7 & 8.2 & 3.3 & 27.0 \\
\hline SJ.E3 & 0.22 & 0.68 & 9.41 & 0.072 & 28.1 & 8.3 & 3.4 & 28.4 \\
\hline SJ.F3 & 0.27 & 0.42 & 6.54 & 0.065 & 35.4 & 8.1 & 4.4 & 38.8 \\
\hline SJ.G4 & 0.32 & 0.64 & 7.76 & 0.082 & 34.5 & 9.4 & 3.7 & 44.7 \\
\hline SJ.H2 & 0.10 & 0.14 & 1.78 & 0.077 & 26.3 & 7.7 & 3.4 & 20.0 \\
\hline SJ.I5 & 0.72 & 0.89 & 7.99 & 0.112 & 21.7 & 9.7 & 2.3 & 17.4 \\
\hline SJ.K4 & 0.36 & 0.53 & 8.79 & 0.061 & 19.8 & 6.0 & 3.3 & 21.2 \\
\hline SJ.L1 & 0.17 & 0.48 & 9.03 & 0.053 & 26.3 & 6.2 & 4.2 & 25.0 \\
\hline SL.M4 & 0.20 & 0.56 & 7.61 & 0.074 & 26.9 & 8.2 & 3.3 & 29.8 \\
\hline SJ.N3 & 0.23 & 0.77 & 10.06 & 0.076 & 26.3 & 8.3 & 3.2 & 23.7 \\
\hline \multicolumn{9}{|l|}{ Statistics } \\
\hline Mean & 0.305 & 0.52 & 7.47 & 0.070 & 26.3 & 7.6 & 3.6 & 26.6 \\
\hline Sd & 0.165 & 0.20 & 2.17 & 0.018 & 4.8 & 1.4 & 0.7 & 7.6 \\
\hline
\end{tabular}

$J_{0}, J_{\mathrm{r}}$ and $J_{\mathrm{s}}$ are the initial remanent, the remanent saturation, and the saturation magnetization, respectively; $H_{\mathrm{cr}}$ is the remanent coercive force; $H_{\mathrm{c}}$ is the coercive force: $J_{\mathrm{rs}}, J_{\mathrm{v}}, H_{\mathrm{cr}}$ and $H_{\mathrm{c}}$ have been determined with a PMC MicroMag 2900 and $H_{\mathrm{cr}}^{\prime}$ using a PM 4 pulse magnetizer.

Using our $H_{\mathrm{cr}}$ values, the data compiled by Day et al. (their table 3), and the diagrams given by O'Reilly (1984) one can conclude that in the lavas of the Jawila Formation (titano)magnetite must be the main carrier of remanence with " $x$ " between 0.2 and 0.3 in the formula $\left(\mathrm{Fe}_{3-x} \mathrm{Ti}_{x} \mathrm{O}_{4}\right)$; moreover, particles with grain size between 3 and $12 \mu \mathrm{m}$ largely contribute to the remanent magnetization of the lavas.

\subsection{Mineral chemistry of magnetites}

For comparison with rock magnetic properties, microprobe and textural observations were made of

\section{Remanence Hysteresis}

\section{SJ.H2B}

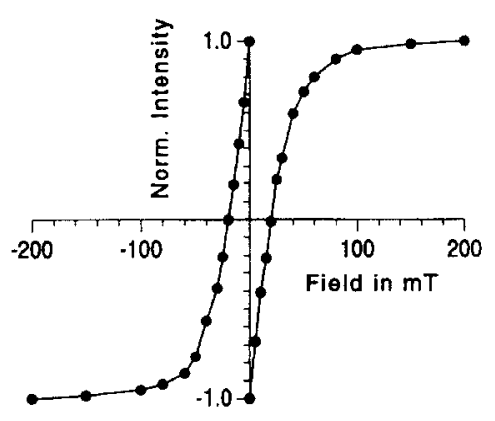

SJ.M4A

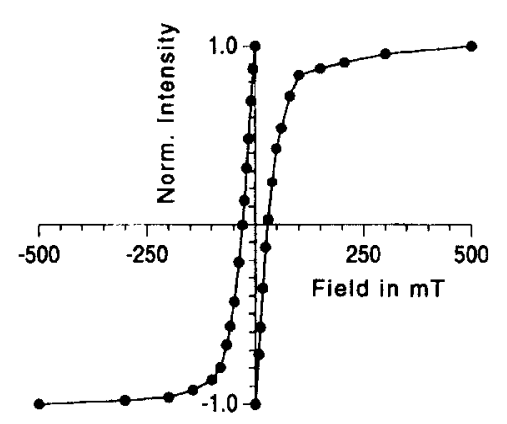

Fig. 4. Normalized acquisition curves of isothernal remanent magnetization of two specimens from the Jawila Formation. The curves indicate the prevalent presence of magnetite as a carrier of remanence. Note the difference in the horizontal scale. 


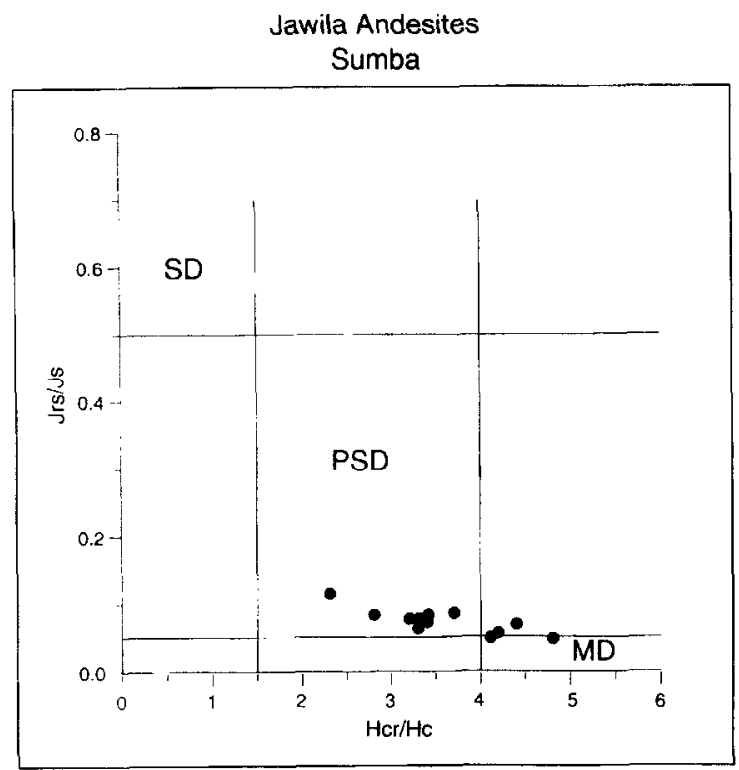

Fig. 5. The $J_{\mathrm{rs}} / J_{\mathrm{s}}$ ratio versus the $H_{\mathrm{cr}} / H_{\mathrm{c}}$ ratio for thirteen specimens of respective sites from the Jawila volcanics (Day et al., 1977). The ratios show that in the majority of the flows the (titano)magnetite is pseudo-single-domain ( $P S D$ ).

magnetites in six samples. The magnetites contain variable amounts of titanium. $\mathrm{TiO}_{2}$ contents range between 0 and 16 wt.\%, which is equivalent to values between 0 and 0.5 for " $x$ " in the formula $\mathrm{Fe}_{3-x} \mathrm{Ti}_{x} \mathrm{O}_{4}$. The titanium contents are highest in the larger grains with dimensions usually between 60 and $300 \mu \mathrm{m}$, rarely up to $500 \mu \mathrm{m}$. The $\mathrm{TiO}_{2}$ content decreases with decreasing grain size. In the groundmass magnetite is generally abundant with grain sizes between 1 and $10 \mu \mathrm{m}$. There is a positive correlation between $\mathrm{Al}_{2} \mathrm{O}_{3}$ and $\mathrm{TiO}_{2}$. The larger (titano)magnetite grains were sometimes found to consist of subgrains of about $10 \mu \mathrm{m}$, scparated by Ti-poor boundaries. Others may show radial or curved fractures and contain Ti-poor patches (SJ.L and SJ.M). The dacites revealed different properties. Groundmass grains in the SJ.A dacite are slightly enriched in $\mathrm{SiO}_{2}$, while in SJ.H the larger grains (up to $100 \mu \mathrm{m})$ are Ti-poor and no groundmass magnetites were identified.

\subsection{Paleomagnetic results}

The characteristic remanence directions of the specimens of eleven sites from the Jawila Formation as well as the site mean direction are plotted in equal area stereograms (Fig. 6). Both the paleomagnetic pole positions and the paleolatitudes derived from the characteristic remanence directions are presented in Table 3. The data are not essentially different from preliminary results from only eleven specimens presented by Chamalaun and Sunata (1982), listed also in Table 3. The latitude at which the Jawila volcanics poured out is not significantly different from the present latitude of the volcanic area on Sumba.

Both our paleomagnetic and mineral chemical studies have shown that in the Jawila lavas (titano)magnetite is the main carrier of remanence. The rapid decrease in remanence intensity during progressive demagnetization as well as the rapid increase in intensity with the application of a direct

Table 3

Paleomagnetic pole positions derived from the early Miocene Jawila Volcanics, western Sumba, Indonesia

\begin{tabular}{|c|c|c|c|c|c|c|c|c|c|c|}
\hline \multirow[t]{2}{*}{ Rock unit } & \multirow[t]{2}{*}{ Age } & \multicolumn{2}{|c|}{ Site coordinates } & \multirow[t]{2}{*}{$N$} & \multicolumn{4}{|c|}{ Pole position } & \multirow[t]{2}{*}{ Palat. } & \multirow[t]{2}{*}{ Data } \\
\hline & & Lat. $\left({ }^{\circ} \mathrm{S}\right)$ & Long. $\left({ }^{\circ} \mathrm{E}\right)$ & & Lat. $\left(^{\circ}\right)$ & Long. $\left(^{\circ}\right)$ & $d p$ & $d m$ & & \\
\hline Jawila Fm & Early Miocene & 9.6 & 119.4 & 11 & $85.5 \mathrm{~N}$ & $213.3 \mathrm{E}$ & 5.4 & 10.3 & $9.9(\mathrm{~S})$ & [1] \\
\hline Jawila Fm & id. & 9.6 & 119.4 & 10 & $86.0 \mathrm{~N}$ & $230.7 \mathrm{E}$ & 5.5 & 10.4 & $11.0(\mathrm{~S})$ & [1] \\
\hline Jawila Fm & id. & 9.6 & 119.4 & 8 & $85.3 \mathrm{~N}$ & $273.6 \mathrm{E}$ & 4.1 & 7.6 & $13.8(\mathrm{~S})$ & [1] \\
\hline Jawila Fm & id. & 9.4 & 119.2 & $11^{*}$ & $81.7 \mathrm{~N}$ & $244.5 \mathrm{E}$ & 5.8 & 10.7 & $14.6(\mathrm{~S})$ & {$[2]$} \\
\hline Massu Fm & Paleocene & 10.0 & 121.0 & 12 & $4.2 \mathrm{~N}$ & $39.3 \mathrm{E}$ & 4.9 & 9.6 & $7.4(\mathrm{~N})$ & [3] \\
\hline Lasipu Fm & Late Cretaceous & 9.7 & 119.6 & 4 & $43.9 \mathrm{~S}$ & $45.8 \mathrm{E}$ & 4.5 & 7.2 & $18.3(\mathrm{~N})$ & {$[3]$} \\
\hline
\end{tabular}

$N$ is the number of sites and $N^{*}$ is the number of specimens included in the final analysis; $d p$ and $d m$ are the semi-axes of the oval of 95\% confidence; Palat. is the paleolatitude in degrees; [1] data from this paper; [2] data from Chamalaun and Sunata (1982); [3] data from Wensink (1994). 


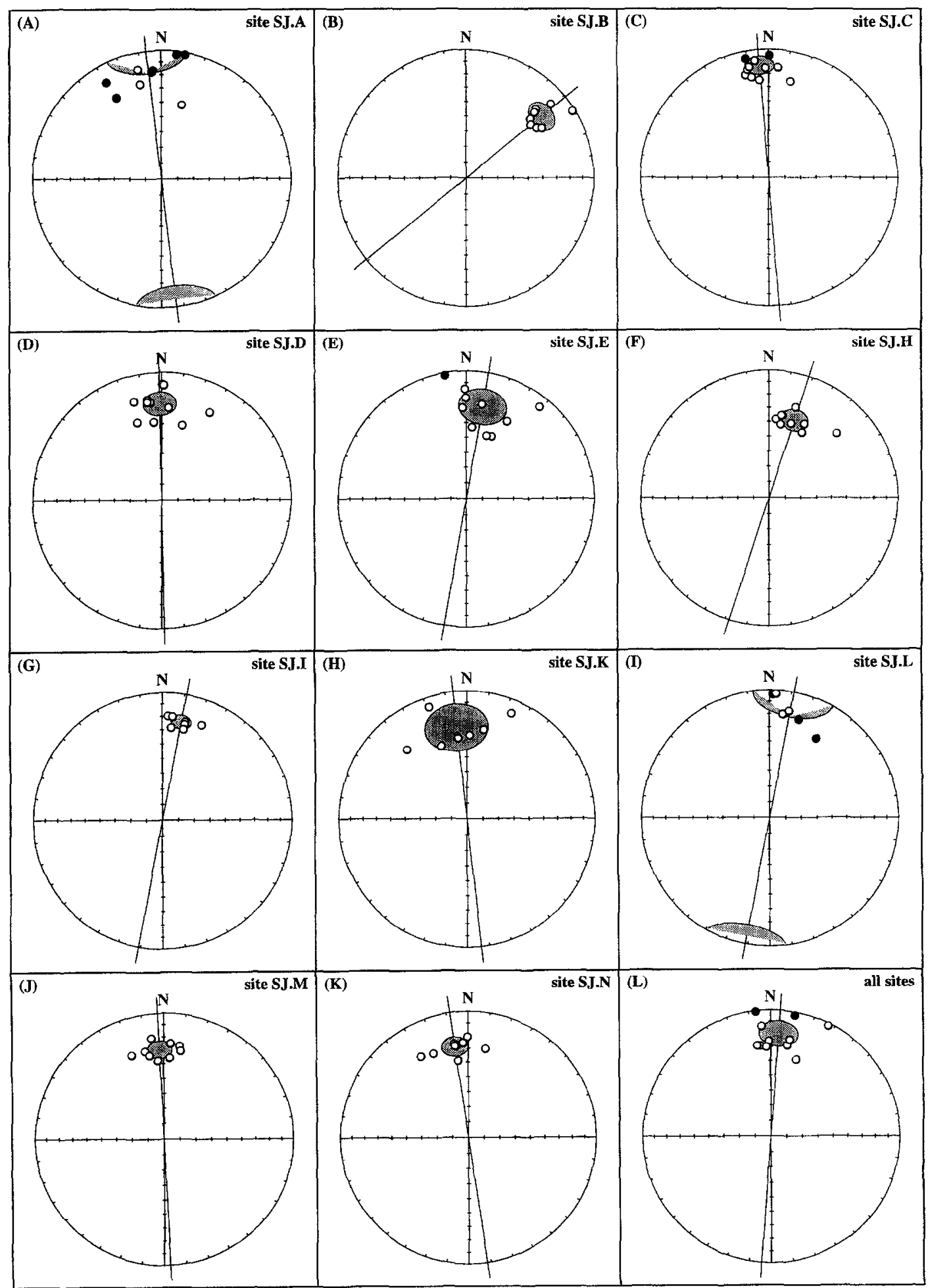


Table 4

Major and trace element compositions of the Jawila volcanics, Sumba

\begin{tabular}{|c|c|c|c|c|c|c|}
\hline & Andesites & & & & Dacites & \\
\hline & SJ.B-E, L-N ${ }^{a}(n=7)$ & SJ.F-G ${ }^{a}(n=2)$ & SJ.I & SJ.K & SJ.A & SJ.H \\
\hline$\overline{\mathrm{SiO}_{2}}$ & 58.4 & 61.0 & 58.5 & 60.1 & 65.5 & 69.6 \\
\hline $\mathrm{TiO}_{2}$ & 0.9 & 1.1 & 1.0 & 0.8 & 0.78 & 0.59 \\
\hline $\mathrm{Al}_{2} \mathrm{O}_{3}$ & 17.1 & 17.0 & 17.7 & 17.3 & 16.3 & 14.9 \\
\hline $\mathrm{Fe}_{2} \mathrm{O}_{3}$ & 8.1 & 7.2 & 8.1 & 7.5 & 5.8 & 4.2 \\
\hline $\mathrm{MnO}$ & 0.15 & 0.14 & 0.15 & 0.15 & 0.13 & 0.11 \\
\hline $\mathrm{MgO}$ & 4.0 & 3.1 & 3.3 & 3.7 & 1.8 & 1.3 \\
\hline $\mathrm{CaO}$ & 5.1 & 4.3 & 5.7 & 3.6 & 1.4 & 2.5 \\
\hline $\mathrm{Na}_{2} \mathrm{O}$ & 3.9 & 4.7 & 4.3 & 5.1 & 6.7 & 5.2 \\
\hline $\mathrm{K}_{2} \overline{\mathrm{O}}$ & $1.3^{h}$ & 1.2 & 1.1 & 1.6 & 1.6 & 1.5 \\
\hline $\mathrm{P}_{2} \mathrm{O}_{5}$ & 0.10 & 0.30 & 0.08 & 0.11 & 0.12 & 0.05 \\
\hline Total & 100.00 & 100.00 & 99.90 & 100.00 & 100.10 & 99.90 \\
\hline LOI & 0.66 & 0.73 & 0.69 & 0.84 & 0.58 & 0.37 \\
\hline $\mathrm{Cr}$ & 7.5 & 4 & 5 & 19 & 10 & 4 \\
\hline Sc & 25 & 24 & 28 & 23 & 20 & 16 \\
\hline $\mathrm{V}$ & 190 & 117 & 216 & 191 & 75 & 77 \\
\hline $\mathrm{Cu}$ & 45 & 24 & 55 & 43 & 15 & 11 \\
\hline $\mathrm{Zn}$ & 76 & 87 & 79 & 64 & 72 & 55 \\
\hline $\mathrm{Rb}$ & $20^{\mathrm{h}}$ & 13 & 27 & 32 & 26 & 28 \\
\hline $\mathrm{Ba}$ & $196^{b}$ & 169 & 135 & 215 & 194 & 180 \\
\hline $\mathrm{Sr}$ & 246 & 295 & 276 & 334 & 276 & 180 \\
\hline $\mathrm{Nb}$ & 4.0 & 7.5 & 3.3 & 4.3 & 3.8 & 5.1 \\
\hline $\mathrm{Hf}$ & 3.6 & 4.6 & 2.5 & 3.0 & 3.5 & 4.8 \\
\hline $\mathrm{Zr}$ & 137.0 & 175.0 & 96.0 & 121.0 & 135.0 & 171.0 \\
\hline$Y$ & 33.0 & 41.0 & 29.0 & 26.0 & 34.0 & 39.0 \\
\hline Th & 1.2 & 1.5 & 0.7 & 1.3 & 1.3 & 2.0 \\
\hline $\mathrm{La}$ & 7.5 & 13.1 & 5.1 & 7.8 & 9.2 & 9.2 \\
\hline $\mathrm{Ce}$ & 20.9 & 32.7 & 14.3 & 21.3 & 2.0 & 28.3 \\
\hline $\mathrm{Sm}$ & 4.0 & 5.8 & 3.1 & 3.4 & 4.0 & 4.65 \\
\hline $\mathrm{Eu}$ & 1.26 & 1.87 & 1.24 & 1.12 & 1.35 & 1.22 \\
\hline $\mathrm{Tb}$ & 0.74 & 1.06 & 0.64 & 0.65 & 0.72 & 0.88 \\
\hline Yb & 3.16 & 3.89 & 2.73 & 2.59 & 3.24 & 3.90 \\
\hline $\mathrm{Lu}$ & 0.48 & 0.59 & 0.40 & 0.38 & 0.52 & 0.57 \\
\hline
\end{tabular}

Major elements and $\mathrm{Cu}, \mathrm{Zn}, \mathrm{Rb}, \mathrm{Ba}, \mathrm{Sr}, \mathrm{Nb}, \mathrm{Zr}$, and $\mathrm{Y}$ were determined by $\mathrm{XRF}$, the other trace elements by INA.

"Average.

' Compositions of samples from flows SJ.B-E and SJ.L-N are relatively constant, except for some variation in $\mathrm{K}_{2} \mathrm{O}, \mathrm{Rb}$ and Ba (e.g., $\mathrm{K}, \mathrm{O}=0.72 \%, \mathrm{Rb}=9 \mathrm{ppm}, \mathrm{Ba}=134 \mathrm{ppm}$ in flow SJ.E; $2.12 \%, 32 \mathrm{ppm}$ and $329 \mathrm{ppm}$ in flow SJ.L).

field of increasing strength point to the significance of (titano)magnetite. Paleomagnetic analysis has indicated that in the formula $\mathrm{Fe}_{3-x} \mathrm{Ti}_{x} \mathrm{O}_{4}$ the value of " $x$ " ranges chiefly between 0.2 and 0.3 ; mineral chemical studies point to a value for " $x$ " between 0 and 0.5 .

The lavas contain a groundmass with abundant magnetite with grain sizes between 1 and $10 \mu \mathrm{m}$;

Fig. 6. Equal area stereograms showing the characteristic remanence directions of both specimens from eleven sites from the Jawila volcanics and the site means. Stereograms from sites SJ.F and SJ.G from the Poronubu Hills are not shown. $O$ and $O$ denote upward-pointing and downward-pointing directions, respectively. Each projection is provided with the mean value; the shaded ellipses give the $\alpha_{45}$ of the overall mean directions. 


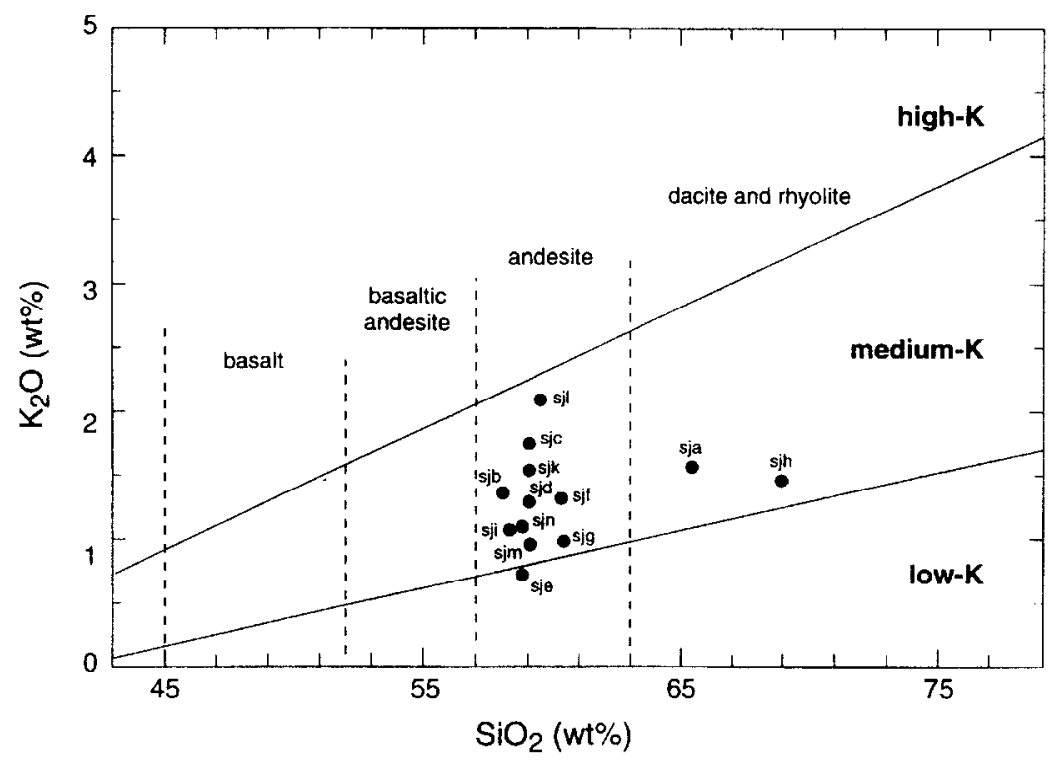

Fig. 7. The Jawila volcanic rocks in the $\mathrm{SiO}_{2}-\mathrm{K}_{2} \mathrm{O}$ classification diagram of Le Maitre (1989).

even larger grains often consist of subgrains of approximately $10 \mu \mathrm{m}$. From the analysis of the magnetic parameters one can conclude that (titano)magnetites with a grain size up to $12 \mu \mathrm{m}$ largely contribute to the magnetization of the volcanics. These data confirm the prevalent presence of pseudomulti-domain (titano)magnetites.

\section{Geochemistry}

Major- and trace-element compositions of samples from all paleomagnetic sites were determined by standard XRF and INA methods, following procedures discussed in Vroon (1992). Results are given in Table 4. In terms of major-element contents, the andesites form a coherent group with limited compositional variation $\left(58-61\right.$ wt. $\left.\% \mathrm{SiO}_{2}\right)$, and plot in the medium-K field of the classification of Le Maitre (1989) (Fig. 7).

The Jawila volcanics contain relatively low concentrations of incompatible trace elements, despite their evolved character. Minor variations in trace-element contents are observed between the andesitic rocks from different sampling sites (cf. Fig. 2). Samples from flows SJ.B, -C, -D, -E and from flows SJ.L, -M, $-\mathrm{N}$ have similar compositions, whereas the flows SJ.I and SJ.K are relatively depleted; the flows SJ.F and SJ.G (Poronubu Mountains) are enriched in rare earth elements (REE), $\mathrm{Y}, \mathrm{Zr}$ and $\mathrm{Nb}$. The dacitic rocks (flows SJ.A and SJ.H) have slightly elevated REE contents but less than the latter andesitic samples.

Normalized incompatible trace-element patterns for all the rocks (Fig. 8) show enrichment in large ion lithophile elements (LILE) relative to MORB and a slight enrichment in light over heavy rare earth elements. Negative $\mathrm{Ti}$ anomalies are indicative of

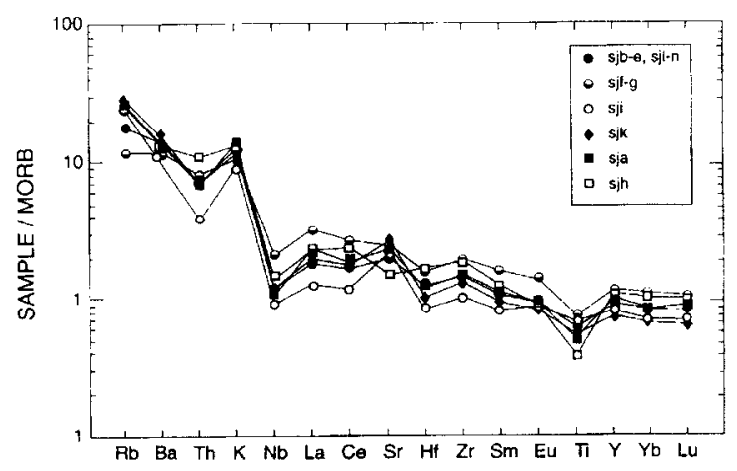

Fig. 8. Incompatible trace element patterns of the Jawila andesites and dacites, normalized on MORB values. 
magnetite fractionation. These trace-elements patterns as well as the high LILE/ $\mathrm{Nb}$ and calc-alkaline nature of the Jawila volcanics point to an origin in a subduction setting.

\section{Discussion and implications for the tectonic emplacement of Sumba}

From the paleomagnetic analysis of the volcanics of the Jawila Formation one can conclude that in early Miocene times the island of Sumba had a position approximately at the same latitude as it has now. Moreover, the paleomagnetic data indicate that Sumba did practically not rotate since the early Miocene; if any, there could have been a clockwise rotation with a maximum of $4^{\circ}$ (Tables 1 and 3). The $\alpha_{95}$ values of the data are rather large; therefore a $\mathrm{N}-\mathrm{S}$-directed shift of Sumba of $4^{\circ}$ with respect to its present position cannot be excluded and a larger amount of rotation is possible as well. However, the preliminary results of a paleomagnetic analysis of the sediments from the middle to late Miocene-early Pliocene Sumba Formation are identical at a much lower $\alpha_{95}$ value (Van der Werff et al., 1995b) supporting the conclusion that at least since the Miocene the continental fragment of Sumba occupied approximately its present position.

Therefore, the main stage of drift must have been prior to this time. Paleomagnetic studies on rocks from Sumba of late Cretaceous and early Tertiary age revealed that in pre-Miocene times the fragment must have performed large rotational and translational movements. The original position of the Sumba fragment had a latitude of $18^{\circ}$, most likely in the northern hemisphere (Wensink, 1994; see also Table 3). The majority of the geological arguments and recent isotopic evidence corroborates this hypothesis (Von der Borch et al., 1983; Audley-Charles et al., 1988; Rangin et al., 1990a, b; Vroon et al., 1995). Simandjuntak (1993) reported striking similarities between late Cretaceous through Miocene stratigraphic sequences of Sumba and southern Sulawesi. $\mathrm{He}$ concluded that in late Cretaceous-Paleogene times the Sumba fragment was positioned east to the South Arm of Sulawesi, in the northern part of the present Bone Bay. However, his suggestion that the separation of the Sumba fragment occurred in early to middle Miocene times, is precluded by our results, according to which it had arrived at or very close to its present position by then.

The geochemical signature of the Jawila volcanics indicates a subduction environment at the time of their formation, which implies that Sumba formed part of a volcanic arc in early Miocene times. This observation is of interest, because of the possible implications for the early stage of development of the East Sunda Arc. The East Sunda Arc can be seen as an eastward propagating extension of the older Sunda Arc of Sumatra and Java (Van Bemmelen, 1949; Katitli, 1975; Abbott and Chamalaun, 1981). On Sumbawa, magmatism was initiated in the early Miocene; after an interruption in middle and late Miocene times volcanic activity resumed in the early Pliocene (Barberi et al., 1987). Fission-track dating of zircons in andesites from Flores yielded an oldest age of $21 \mathrm{Ma}$ (Nishimura et al., 1981), but from central Flores ages of no more than 4 Ma have been reported (Abbott and Chamalaun, 1981). Further east the oldest dated igneous rocks are $12 \mathrm{Ma}$ samples from the island of Wetar (Fig. 1) in the extinct sector north of Timor (Abbott and Chamalaun, 1981). The active Banda Arc is considerably younger.

The available geochronological data thus suggest that magmatic activity of an age similar to that of the Jawila volcanics occurred on Sumbawa and eastern Flores but may absent in the area between these two locations. We hypothesize, therefore, that Sumba and its surroundings formed part of the proto-East Sunda Arc during part of the Miocene. This leaves two options for the current position of Miocene arc volcanics south of the present East Sunda Arc:

(1) The Jawila rocks represent magmas from the (proto-) East Sunda Arc and originated slightly more to the north within the present domain of the volcanic arc. Near the end of its drift from north to south, Sumba passed the zone of magma generation in this sector of the (proto-) East Sunda Arc, and carried the volcanics, detached from their mantle sources, over a relatively short distance $(300 \mathrm{~km}$ at most) southward. This would imply that the Sumba fragment reached its final position when the volcanic arc already had started to develop, and that the western and eastern sides of the microcontinent are presently bound by major discontinuitics across the arc system. In this case the East Sunda Arc is 
assumed to have remained stationary at the same latitude since its formation.

The statistical error in our paleomagnetic data on the Jawila volcanics permits such a minor southward drift since the early Miocene. On the other hand, the available data would also allow a slightly more southward Miocene position of the Sumba fragment rather than a northward one; the paleolatitude data derived from both the Jawila and the overlying Sumba Formation (Van der Werff et al., 1995b) would not be in conflict with a minor post early Pliocene drift of the Sumba block to the north (cf. Audley-Charles, 1975).

Therefore, relative to the present volcanic arc, slightly different positions of the Sumba fragment are conceivable: either within the region of the present arc at its current location, or somewhat more to the south.

(2) The Jawila magmas originated at their present location after the drift of Sumba had come to a complete end. They represent an early manifestation of volcanic activity in this part of the East Sunda Arc. Assuming a single arc system, this would imply that in the early Miocene the volcanic front had a more southern position than in the adjacent sectors, and that it shifted northward to the present arc since then, perhaps after a period of volcanic rest.

Such a shift has been proposed by Fortuin et al. (1994), based on the presence of abundant volcanic material in the Neogene deposits of the Sumba Formation; the NNE-prograding submarine fans and outcrops along eastern Sumba's south coast point to a provenance from a proto-volcanic arc to the south of the island. Seismo-stratigraphic research has confirmed the eastward continuation of these deposits in the Sumba Basin, on the submarine Sumba Ridge and in the South Savu Basin (Van der Werff et al., 1994a; Van der Werff, 1995). Since the front of the accretionary wedge has approached Sumba's south coast at a distance of less than $50 \mathrm{~km}$, it is unlikely that any trace of this presumed proto-volcanic arc is left (Van der Werff et al., 1995a). Eastward the wedge widens and backthrusts cut off the submarine continuation of Sumba in the South Savu Basin. The Jawila volcanics in western Sumba may represent a rather small advanced continuation of the same postulated arc.

Significant shifts of the volcanic front suggests changes in the subduction geometry since the Miocene, which are likely to have occurred in response to the arc-continent collision. They could be the effect of the transition in the subducting plate from oceanic to continental lithosphere. As long as subduction occurred in an entirely oceanic environment, the downgoing slab of probably late Jurassic age, and therefore relatively cold and dense, was steep, resulting in a short arc-trench gap. Upon the arrival of the Australian continental margin, subduction of its leading edge with much more buyoant material, may have caused a flattening of the dip and a concomitant widening of the arc-trench gap, which could explain the northward shift of the volcanic front. Sections across the present-day seismic Benioff zone in the collision region east of $116^{\circ} \mathrm{E}$ suggest such a change in dip: it is relatively flat in the shallow parts and steep at deeper levels to the north (McCaffrey, 1989).

Furthermore, the gradually increasing supply of sedimentary material of the approaching passive margin has led to the formation of the voluminous accretionary prism south and southeast of Sumba. Sediment accretion, subduction and subduction erosion in areas with accretionary wedge formation may be accompanied by changes in the geometry of the subduction zone. Such features have been documented for the Cenozoic tectonic history of northern Honshu in Japan by Von Huene et al. (1982), who attributed the presence of Tertiary volcanic rocks in the fore-arc area to changes in the geometry as well.

Because a more southern position of the early Miocene volcanic front in the East Sunda Arc may have been limited to the Sumba area, the controls of the subduction geometry may have varied over relatively short distances along the strike of the arc system. Given the likely relation with the collision process, the variation could reflect irregularities in the outline of the approaching Australian margin, similar to those along its northwestern border with the Indian Ocean.

We conclude from our paleomagnetic results that the drift of the Sumba fragment, which started at the eastern rim of Sundaland in late Cretaceous times, had practically ended in the early Miocene. Unequivocal evidence on whether Sumba reached its final position shortly after or before the extrusion of the Jawila volcanics remains to be established. From 
circumstantial evidence there is a slight preference for the second option. It should be noted, however, that both possibilities preclude the presence of arctype magmatic rocks in the East Sunda sector to the north of Sumba with the same age as the Jawila Formation, except when two parallel arc systems existed simultaneously. Further verification requires detailed age dating of the Tertiary magmatic rocks in this part of the Sunda-Banda Arc.

\section{Acknowledgements}

This work has been supported by the Netherland's Council for Sea Research (SOZ) in the Hague. The logistic support of the Marine Geological Institute (MGI) and the Research and Development Centre for Geotechnology with its director Ir. S. Suparka (LIPI), both in Bandung, is greatly acknowledged. Thanks are due to Dr. Wadhjoe, Mr. Suharno, Mr. Saban and Drs. Berghuis for their pleasant help in the field. We are grateful to Dr. C.G. Langereis and Mr. Mullender of the Paleomagnetic Laboratory for their support as well as to Dr. A.R. Fortuin and Mr. Van der Werff for fruitful discussions. We thank Henrich Grönloh for geochemical research, and Tilly Bouten, Theo van Zessen and Thea van Meerten (IRI, Delft) for analytical assistance. The electron microprobe in Utrecht is financially supported by NWO-AWON (GOA). Dr. R. van der $\mathrm{Voo}$ and an anonymous reviewer are thanked for their critical and useful comments.

\section{References}

Abbott, M.J. and Chamalaun, F.H., 1981. Geochronology of some Banda arc volcanics. In: A.J. Barber and S. Wiryosujono (Editors), Geology and Tectonics of Eastern Indonesia. Indones. Geol. Res. Dev. Cent., Spec. Publ., 2: 253-268.

Audley-Charles, M.G., 1975. The Sumba fracture: a major discontinuity between eastern and westem Indonesia. Tectonophysics, 26: $213-218$.

Audley-Charles, M.G., 1985. The Sumba enigma: is Sumba a diapiric fore-arc nappe in proces of formation? Tectonophysics, 119: 435-449.

Audley-Charles, M.G., Ballantyne, P.D. and Hall, R., 1988. Mesozoic-Cenozoic rift-drift sequence of Asian fragments from Gondwanaland. Tectonophysics, 155: 317-330.

Barber, A.J., 1981. Structural interpretation of the island of Timor,
Indonesia. In: A.J. Barber and S. Wiryosujono (Editors), Geology and Tectonics of Eastern Indonesia. Indones. Geol. Res. Dev. Cent., Spec. Publ., 2: 183-197.

Barberi, F., Bigioggero, B., Boriani, A., Cattaneo, M.. Cavallin, A., Cioni, R., Eva, C.. Celmini, R., Giorgetti, F., Jaccarino, S., Innocenti, F., Maricelli, G., Slejko, D. and Dudratjat, A., 1987. The island of Sumbawa: a major structural discontinuity of the Indonesian Arc. Boll. Soc. Geol Ital., 106: 547-620.

Berry, R.F. and McDougall, I.A., 1986. ${ }^{41} \mathrm{Ar} /{ }^{36} \mathrm{Ar}$ and $\mathrm{K} / \mathrm{Ar}$ dating evidence from the Aileu Formation. East Timor, Indonesia. Chem. Geol., 59: 43-58.

Burrolet, P. and Sallé, C., 1982. Histoire géologique de l'île de Sumba (Indonésie). Bull. Soc. Géol. Fr., 24: 573-590.

Chamalaun, F.H. and Sunata, W., 1982. The paleomagnetism of the Western Banda Arc System-Sumba. In: Paleomagnetic Research in Southeast and East Asia. Proc. Workshop, Kuala Lumpur, March 1982, CCOP. Bangkok. pp. 162 -194.

Chamalaun, F.H., Grady, A.E., Von der Borch, C.C. and Hartono, H.S.M., 1981. The tectonic significance of Sumba. Bull. Indones. Geol. Res. Dev. Cent., 5: 1-20.

Chappell, J. and Veeh, H.H., 1978. Late Quaternary tectonic movements and sea level changes at Timor and Atauro Island. Geol. Soc. Am. Bull., 89: 356-368.

Charlton, T.R., 1991. Postcollision extension in arc-continent collision zones, eastern Indonesia. Geology, 19: 28-31.

Day, R., Fuller, M.D. and Schmidt, V.A., 1977. Magnetic hysteresis properties of titanomagnetites: grain size and compositional dependence. Phys. Earth Planet. Inter., 13: 260-267.

De Smet, M.E.M., Fortuin, A.R., Tjokosapoetro, S. and Van Hinte, J.E., 1989. Late Cenozoic vertical movements of nonvolcanic islands in the Banda Arc area. Neth. J. Sea Res., 24: 263-275.

Effendi, A.C. and Apandi, T., 1981. Geological map of the Sumba Quadrangle, Nusatenggara. Geol. Res. Dev. Cent., Bandung.

Eva, C., Cattaneo, M. and Merlanti, F., 1988. Seismotectonics of the central segment of the Indonesian arc. Tectonophysics, 146: $241-259$.

Fisher, A.G., 1953. Dispersion on a sphere. Proc. R. Soc. London, Ser. A, 217: 295--305.

Fortuin, A.R., Roep, T.B., Sumosusastro, P.A.. Van Weering, T.C.E. and Van der Werff, W., 1992. Slumping and sliding in Miocene and Recent developing arc basins, onshore and offshore Sumba (Indonesia). Mar. Geol., 108: 345363.

Fortuin, A.R., Roep, T.B. and Sumosusastro, P.A., 1994. The Neogene sediments of East Sumba, Indonesia-products of a lost arc? J. Southeast Asian Earth Sci., 9: 67-80.

Hamilton, W.. 1979. Tectonics of the Indonesian Region. Geol. Surv. Prof. Pap. 1078, 345 pp.

Harris. R.A., 1991. Temporal distribution of strain in the active Banda orogen: a reconciliation of rival hypotheses. J. Southeast Asian Earth Sci., 6: 373-386.

Hartstra, R.L., 1982. Grain-size dependence of initial susceptibility and saturation magnetization-related parameters of four natural magnetites in the PSD-MD range. Geophys. J. R. Astron. Soc., 71: 477-495.

Hilton, D.R., Hoogewerff, J.A., Van Bergen. M.J. and Hammerschmidt, K.. 1992. Mapping magma sources in the east 
Sunda-Banda arcs; Indonesia: constraints from helium isotopes. Geochim. Cosmochim. Acta, 56: 851-859.

Johnston, C.R. and Bowin, C.O., 1981. Crustal reactions resulting from the Mid-Pliocene to Recent continental-island arc collision in the Timor region. BMR Aust. Geol. Geophys., 6: 223-243.

Katitli, J.A., 1975. Volcanism and plate tectonics in the Indonesian island arcs. Tectonophysics, 26: 165-188.

Karig, D.E., Barber, A.J., Charlton, T.R., Klemperer, S. and Hussong, D.M., 1987. Nature and distribution of deformation across the Banda arc-Australian collision zone at Timor. Geol. Soc. Am. Bull., 98: 18-32.

Laufer, F. and Kraeff, A., 1957. The geology and hydrology of West- and Central-Sumba and their relationship to the water supply and the rural economy (with maps). Publ. Keilmuan, Ser. Geol. 33, 48 pp.

Le Maitre, R.W. (Editor), 1989. A Classification of Igneous Rocks and Glossary of Terms. Blackwell, Oxford, 193 pp.

McCaffrey, R., 1989. Seismological constraints and speculations on Banda Arc tectonics. Neth. J. Sea Res., 24: 141-152.

Nishimura, S., Otofuji, Y., Ikeda, T., Abe, E., Yokohama, T., Kobayashi, Y., Hadiwisastra, S., Sophaluwakan, J. and Hehuwat, F., 1981. Physical geology of the Sumba, Sumbawa and Flores islands. Indones. Geol. Res. Dev. Cent., Spec. Publ., 2: 105-113.

Norvick, M.S., 1979. The tectonic history of the Banda Arcs, eastern Indonesia: a review. J. Geol. Soc. London, 136: 519527.

O'Reilly, W., 1984. Rock and Mineral Magnetism. Blackie, Glasgow, $220 \mathrm{pp}$.

Otofuji, Y., Sasajima, S., Nishimura, S., Yokoyama, T., Hadiwisastra, S. and Hehuwat, F., 1981. Paleomagnetic evidence for the paleoposition of Sumba Island, Indonesia. Earth Planet. Sci. Lett., 52: 93-100.

Pirazzoli, P.A., Radtke, U., Hantoro, W.S.. Jouannic, C.. Hoang, C.T., Causse, C. and Borel Best, M., 1991. Quartenary raised coral-reef terraces on Sumba Island, Indonesia. Science, 252: 1834-1837.

Rangin, C., Jolivet. L., Pubellier, M. and the Tethys Working Group, 1990a. A simple model for the tectonic evolution of southeast Asia and Indonesia for the past 43 m.y. Bull. Soc. Géol. Fr., 8: 889-905.

Rangin, C., Pubellier, M., Azéma, J. and the Tethys Pacific Working Group, 1990b. The quest for Tethys in the westem Pacific. 8 paleogeodynamic maps for Cenozoic time. Bull. Soc. Géol. Fr., 8: 907-913.

Silver, E.A., Reed, D.L., McCaffrey, R. and Joyodiwiryo, Y., 1983. Back arc thrusting in the eastern Sunda Arc, Indonesia; a consequence of arc-continent collision. J. Geophys. Res., 88: 7429-7448.
Simandjuntak, T.O., 1993. Tectonic origin of Sumba platform. J. Geol. Sumberdaya Mineral., 3: 10-19.

Van Bemmelen, R.W., 1949. Geology of Indonesia. Nijhoff, the Hague, pp. 156-159, pp. 507-510.

Van Bergen, M.J., Vroon, P.Z. and Hoogewerff, J.A.. 1993. Geochemical and tectonic relationships in the east Indonesian arc-continent region: implication for the subduction of the Australian passive margin. Tectonophysics, 223: 97-116.

Van der Werff, W., 1995. Forearc basin response to arc/continent collision (The Cenozoic evolution of the Savu Basin). J. Mar. Pet. Geol. (in press).

Van der Werff, W., Kusnida, D., Prasetyo, H. and Van Weering, T.C.E., 1994a. Origin of the Sumba forearc basement. Mar. Pet. Geol., 11: 363-374.

Van der Werff, W., Prasetyo, H., Kusnida, D. and Van Weering, T.C.E., 1994b. Seismic stratigraphy and Cenozoic evolution of the Lombok Forearc Basin, eastern Sunda Arc. Mar. Geol. 117: $119-134$.

Van der Werff, W., Kusnida, D., Prasetyo, H. and Van Weering, T.C.E., 1995a. Structure and morphotectonics of the accretionary prism in the Eastern Sunda/Western Banda Arc. J. Southeast Asian Earth Sci. (in press).

Van der Werff, W., Fortuin, A.R. and Wensink, H., 1995 b. Neogene basin history and paleomagnetism of a developing forearc region-onshore and offshore Sumba (Eastern Indonesia). In: W. Van der Werff, Forearc Development and Early Orogenesis along the Eastern Sunda-Western Banda Arc. Ph.D. Thesis, Free University, Amsterdam.

Van Weering, T.J.C., Kusnida. D., Tjokrosapoetro, S., Lubis, S., Kridoharto, P. and Munadi, S., 1989. The seismic structure of the Lombok and Savu Forearc Basins, Indonesia. Neth. J. Sea Res., 24: 251-262.

Von der Borch, C.C.. Grady, A.E., Hardjoprawiro, S., Prasetyo, H. and Hadiwisastra, S., 1983. Mesozoic and Late Tertiary submarine fan sequences and their tectonic significance. Sumba. Indonesia. Sediment. Geol.. 37: 113-132.

Von Huene, R., Langseth, M., Nasu, H. and Okada, H., 1982. A summary of Cenozoic tectonic history along the IPOD Japan Trench transect. Geol. Soc. Am. Bull., 93: 829-846.

Vroon, P.Z., 1992. Subduction of continental material in the Banda Arc, Eastern Indonesia. Geol. Ultraiectina, 205 pp.

Vroon, P.Z., Van Bergen, M.J. and Forde, E., 1995. Pb-Nd isotope constraints on the provenance of tectonically dispersed continental fragments in East Indonesia. Geol. Soc. Spec. Bull. (in press).

Wensink, H., 1994. Paleomagnetism of rocks from Sumba: tcctonic implications since the late Cretaceous. J. Southeast Asian Earth Sci.. 9: 51-65. 